\title{
Magnitude and Frequency of Temperature and Precipitation Extremes and the Associated Atmospheric Circulation Patterns in the Yellow River Basin (1960-2017), China
}

\author{
Xiaogang Dong ${ }^{1,2}$, Shiting Zhang ${ }^{2, *}$, Junju Zhou ${ }^{1}$, Jianjun Cao ${ }^{1}$, Liang Jiao ${ }^{1}$, Zhiyang Zhang ${ }^{2}$ \\ and Yang Liu ${ }^{2}$ \\ 1 College of Geography and Environmental Science, Northwest Normal University, Lanzhou 730070, China; \\ dongxg121@163.com (X.D.); yzh_su@163.com (J.Z.); caojj@nwnu.edu.cn (J.C.); jiaoliang@nwnu.edu.cn (L.J.) \\ 2 State Key Laboratory of Grassland Agro-ecosystems, School of Life Sciences, Lanzhou University, Lanzhou \\ 730000, China; zhangzhy19@lzu.edu.cn (Z.Z.); liuyang2018@lzu.edu.cn (Y.L.) \\ * Correspondence: zhangsht@lzu.edu.cn
}

Received: 14 September 2019; Accepted: 5 November 2019; Published: 7 November 2019

\begin{abstract}
Since there are many destructive effects caused by extreme climate events in the Yellow River, it is of great theoretical and practical significance to explore the variations of climatic extremes in this key basin. We used a meteorological dataset from 66 stations within the Yellow River basin (YRB) for the period 1960-2017 to calculate magnitude and frequency of precipitation/temperature extremes. We also analyzed the relationships between the main large-scale atmospheric circulation patterns (ACPs) and precipitation/temperature extremes. The trends in precipitation extremes were nonsignificant, only a few stations were characterized by significantly increasing or decreasing anomalies; this indicates the precipitation intensity may have been strengthened, and the extreme rainfall duration appears to have been reduced during 1960-2017. The trends of magnitudes for "cold" extremes were larger than those for "warm" extremes, changes of trends in frost days were higher than those for summer days, and the trends in increasing warm nights were higher than those of warm days. The influence of the El Niño-Southern Oscillation (ENSO) and Arctic Oscillation (AO) on temperature extremes outweighed the influence of the North Atlantic Oscillation (NAO), Indian Ocean Dipole (IOD), and Pacific Decadal Oscillation (PDO) for the other extreme climate indices. The YRB might be at risk of increased extreme high temperature events, and more attention should be paid to this higher risk of extreme climatic events.
\end{abstract}

Keywords: precipitation; temperature; climatic extremes; atmospheric circulation patterns; the Yellow River basin

\section{Introduction}

Global warming is the result of increased carbon dioxide and other greenhouse gases concentrations, and it is likely to have some climatic and weather hazards on the eco-environments worldwide [1-4], leading to losses of property and human lives [5] due to floods, droughts, and cyclones. Climate change is largely expressed by temperature and precipitation variability, and extreme precipitation intensity will continue to strengthen as global warming continues [6-8]. According to the investigated results of the Intergovernmental Panel on Climate Change [9], of particular importance are possible changes in extreme events over large parts of the world, including the intensity, frequency, timing, and extent of those climate-related extremes. 
Some evaluations of numerical climate model simulations and observational records revealed that the annual average precipitation was increasing with increasing mean temperature at regional and global scales [2,10,11]. Zhang et al. [12] used the Soil and Water Assessment Tool (SWAT) and utilized global climate model simulations (three scenarios) to forecast the future climate conditions for 2013-2042; they suggested that there is an increasing trend in annual rainfalls under all scenarios and pronounced warming trends in temperature. However, Pierre and Ayan [13] noted that precipitation decreased with increasing temperature in Djibouti city from 1966 to 2011.

Additionally, the fact that variability of climatic extremes indices is more sensitive than the mean values of climate change $[6,7,14]$ has been universally acknowledged by the scientific community. Studies showed that increasing temperatures and/or precipitations can strengthen the climatic extremes [15-17], which could possibly lead to changes in precipitation frequency, amount, and intensity; river flow; soil moisture content; and evapotranspiration rate on regional and global scales $[1,8,18]$. For example, the increase of precipitation was due to the increase of the rain frequency and intensity in the Chinese Tianshan Mountains from 1961 to 2011 [19], the heavy precipitation frequency increased with significant increasing temperature [17], the heavy and sustained precipitation events led to waterlogging, landslides, and some other disasters over part of central-eastern China, resulting in severe damage to crops in the lower reaches of the Yangtze River [20].

More and more evidence from climate models shows that most temperature indices that are derived from daily minimum temperature are changed as a result of warming [21-23], and the trend of daily minimum temperature warming has a greater impact than that from maximum temperature [24]. For example, in the Djibouti City of eastern Africa, extreme temperatures $\left(\geq 45^{\circ} \mathrm{C}\right)$ in the past decade were 15 times more frequent than in the period 1966-1975, while extremely cold nights with a minimum temperature equal to or lower than $8.6^{\circ} \mathrm{C}$ disappeared during 1966-2011 [13]. A study in Poland also indicated that fifteen out of sixteen of the warmest years on record (1880-2015) occurred since 2001. This means that each of the past fifteen years since 2001 has been warmer by at least $0.54{ }^{\circ} \mathrm{C}$ than the long-term average from 1910 to 2000 [25]. In short, the variability of climatic extremes in different regions tends to be different because of the huge differences in climate driving forces and regional terrain characteristics.

China is the third largest land area in the world. The complicated nature and geography of the environment causes many climatic disasters, and these are directly influenced by the spatiotemporal variation of precipitation $[20,26,27]$. Great attention has been paid to extreme precipitation and temperature due to the global warming and rapid urbanization in China. The Yellow River is the second longest river in China and the fifth largest river in the world; characterized by uneven temporal-spatial patterns of precipitation, it has attracted more studies that focused on climate variations. Many researchers in the early 1960s focused on the entirety or sub-regions of the Yellow River basin (YRB) and investigated the variations of precipitation and/or temperature. Zhao et al. [28] pointed out the annual temperature rose $0.80^{\circ} \mathrm{C}$ in the upstream areas of the YRB from 1960 to 2001, but annual precipitation was not significant during the same period. Liu et al. [26] examined the spatiotemporal variability of annual precipitation all along the YRB, and results showed that most regions exhibited prominent decreasing trends of precipitation in the whole basin from 1961 to 2006. Yang and Liu [29] used 80 meteorological stations to determine that $83.75 \%$ of stations displayed decreasing trends with a reduction of $10.37 \%$ in annual precipitation during 1961-2000. Nevertheless, the precipitation extreme indices have a declining trend and the temperature extreme indices show the patterns of variability consistent with a general warming trend in the YRB over the past few decades [30]. Meanwhile, Wang et al. [15] noted decreasing trends in most extreme rainfall indices and increasing trends in extreme temperature indices in winter due to the increasing frequency of warm days and warm nights, and the decreasing frequency of cold days and cold nights. Dong et al. [31] reported that extreme rainfall events showed a negative trend along the middle and lower reaches of the YRB from 1951 to 2004. Gao et al. [4] explored the spatial and temporal variations and causes of precipitation extremes over the YRB from 1960 to 2011. 
One of the physical mechanisms of climatic extremes is atmospheric circulation [32,33], and lead to a variety of precipitation extremes [34-37]. Some examples of atmospheric patterns are the El Niño-Southern Oscillation (ENSO), the Arctic Oscillation (AO), the Pacific Decadal Oscillation (PDO), the Indian Ocean Dipole (IOD), and the North Atlantic Oscillation (NAO) [9]. These atmospheric circulation patterns (ACPs) are identified by the continuous, recurring, and large-scale modes of pressure anomalies. The ACPs are commonly expressed by numerical indices determining the intensity of the influence of atmospheric circulation during a specific period in a particular geographical region. Studies around the world revealed the influence of the large-scale atmospheric circulation changes on weather regimes, climate change, and hydrological variations [38-43]. China climate types are mainly governed by the East Asian Monsoon. Nevertheless, the East Asian Summer Monsoon is significantly influenced by the ENSO [38,44], the PDO [45], the AO [46], the IOD, and the NAO [43]. Global ENSO events, which directly affected the regional precipitation in the river basin, resulted in an approximately $51 \%$ decrease in river water discharge to the sea [47].

Here, we built on the existing literature to identify probable responses to the behavior of the atmospheric circulation patterns. Consequently, in this study, we extended these ACPs and attempted to solve the following three problems: (i) What are the trends in the changes of magnitude and frequency of temperature and precipitation extremes in the YRB? (ii) Can the ACPs that influence the climate of the YRB also have significant effects on extreme climate events in the YRB? If so, (iii) how and to what extent can they impact extreme climate events? Our principal objectives were to (i) analyze the temporal and spatial variations of daily temperature and precipitation extremes in the YRB during 1960-2017 and (ii) investigate the ACPs (ENSO, AO, NAO, PDO, and IOD) associated with these extreme indices by using the Pearson correlation analysis method and to interpret possible mechanisms based on the ACPs for observed changes in the YRB from 1960 to 2017. This research can provide a scientific basis for the studies of natural disasters in the whole basin of the Yellow River or its regions as a response to global climate change.

\section{Data and Methods}

\subsection{Data}

The homogenized daily minimum and maximum temperature and precipitation data from 66 meteorological stations in the YRB (Figure 1) from 1960 to 2017 were obtained from the Climate Data Center of China, National Meteorological Information Center (Available online: http://www.nmic. gov.cn/). The ACPs' (ENSO, AO, NAO, PDO, and IOD) indices for the same period were collected from the National Oceanic and Atmospheric Administration's National Centers for Environmental Information (available at https://www.ncdc.noaa.gov/teleconnections/). In addition, three typical regions in the YRB were selected to further investigate the multi-timescale characteristics of the climate extremes. As shown in Figure 1, these regions, defined by latitude and longitude, reflect climatic and landform conditions in the YRB. To ensure that the best data sources were used, quality control was performed using the RClimDex software (Climate Research Branch Environment Canada, Downsview, ON, Canada) from the CCl/CLIVAR/JCOMM Expert Team on Climate Change Detection and Indices ETCCDI [48] with the aim of identifying the errors in data processing. After data quality control and homogeneity, sixteen extreme indices (Table 1) were selected. These indices are widely used to evaluate the changes in climate extremes [22,49-51]. The possible associations between the chosen indices and the ACPs were analyzed by a multiple regression method. All the climatic indices were available at the monthly scale. In our analysis, we averaged the monthly values to calculate the annual mean. The temporal and spatial variations in temperature and precipitation extremes were analyzed using Origin Pro 8.0 (OriginLab Corporation, Northampton, MA, USA), SPSS 22.0 (SPSS Inc., IBM, New York, NY, USA) and ArcGIS 10.2 (ESRI, Redlands, CA, USA). 


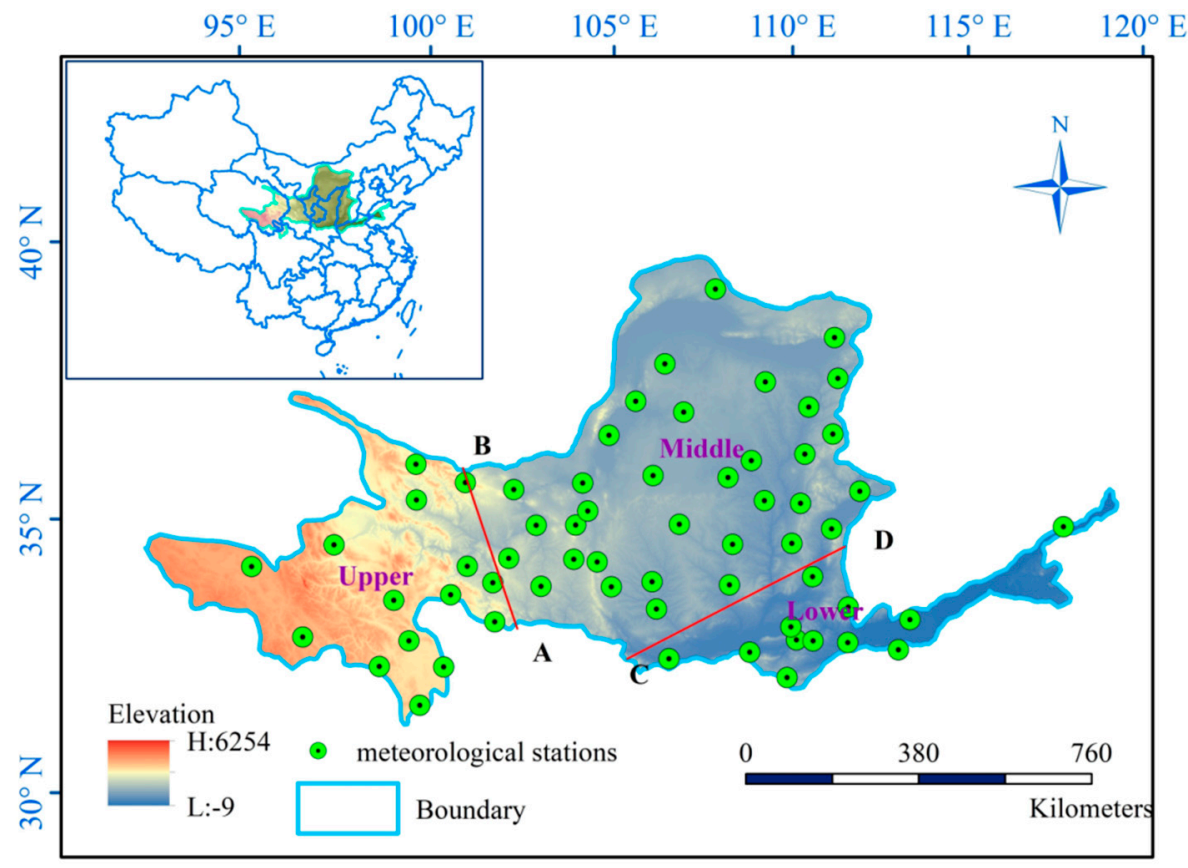

Figure 1. The Digital Elevation Model (DEM) and location of the meteorological stations in this study. The two straight lines dividing the basin into three regions are from the following points: $\mathrm{A}\left(34^{\circ} 15^{\prime} \mathrm{N}\right.$, $\left.104^{\circ} 45^{\prime} \mathrm{E}\right) ; \mathrm{B}\left(37^{\circ} 10^{\prime} \mathrm{N}, 103^{\circ} 00^{\prime} \mathrm{E}\right) ; \mathrm{C}\left(34^{\circ} 15^{\prime} \mathrm{N}, 107^{\circ} 15^{\prime} \mathrm{E}\right)$; and $\mathrm{D}\left(36^{\circ} 45^{\prime} \mathrm{N}, 112^{\circ} 30^{\prime} \mathrm{E}\right)$.

Table 1. Definitions of the temperature and precipitation indices used in this study.

\begin{tabular}{|c|c|c|}
\hline Index (Unit) & Description Name & Definition \\
\hline FD (days) & Frost days & Annual count of days when $\mathrm{TN}<0^{\circ} \mathrm{C}$ \\
\hline SU (days) & Summer days & Annual count of days when $\mathrm{TX}>25^{\circ} \mathrm{C}$ \\
\hline $\mathrm{TXx}\left({ }^{\circ} \mathrm{C}\right)$ & Hottest day & The maximum value of $\mathrm{TX}$ records \\
\hline $\mathrm{TNn}\left({ }^{\circ} \mathrm{C}\right)$ & Coldest night & The minimum value of $\mathrm{TN}$ records \\
\hline TN10p (days) & Cold nights & $\begin{array}{c}\text { Percentage of days when } \mathrm{TN}<10 \text { th } \\
\text { percentile }\end{array}$ \\
\hline TX10p (days) & Cold days & $\begin{array}{l}\text { Percentage of days when } \mathrm{TX}<10 \text { th } \\
\text { percentile }\end{array}$ \\
\hline TN90p (days) & Warm nights & $\begin{array}{l}\text { Percentage of days when } \mathrm{TN}>90 \text { th } \\
\text { percentile }\end{array}$ \\
\hline TX90p (days) & Warm days & $\begin{array}{l}\text { Percentage of days when } \mathrm{TX}>90 \text { th } \\
\text { percentile }\end{array}$ \\
\hline CDD (days) & Consecutive dry days & $\begin{array}{c}\text { Maximum number of consecutive days } \\
\text { with } \mathrm{RR}<1 \mathrm{~mm}\end{array}$ \\
\hline RX1day (mm) & Maximum 1-day precipitation & Monthly maximum 1-day precipitation \\
\hline RX5day (mm) & Maximum 5-day precipitation & $\begin{array}{l}\text { Monthly maximum consecutive 5-day } \\
\text { precipitation }\end{array}$ \\
\hline R10mm (days) & Heavy precipitation days & Annual count of days when $R R \geq 10 \mathrm{~mm}$ \\
\hline $\mathrm{R} 25 \mathrm{~mm}$ (days) & Heaviest precipitation days & $\begin{array}{c}\text { Annual count of days when } R R \geq 25 \mathrm{~mm} \\
\text { Annual total precipitation when } R R>\end{array}$ \\
\hline $\mathrm{R} 95 \mathrm{p}(\mathrm{mm})$ & Very wet day precipitation & $\begin{array}{l}\text { 95th percentile of 1960-2017 daily } \\
\text { rainfall }\end{array}$ \\
\hline R99p (mm) & Extremely wet day precipitation & $\begin{array}{c}\text { Annual total precipitation when RR > } \\
\text { 99th percentile of 1960-2017 daily } \\
\text { rainfall }\end{array}$ \\
\hline SDII (mm/day) & $\begin{array}{l}\text { Simple precipitation intensity } \\
\text { index }\end{array}$ & Average precipitation on wet days \\
\hline
\end{tabular}

Note: TX: daily maximum temperature; TN: daily minimum temperature; RR: daily precipitation. 


\subsection{Trend Analysis}

The non-parametric Mann-Kendall (M-K) test and Sen's slope estimates were used to calculate trends in the selected time series of temperature and precipitation extremes for the YRB. The M-K test is widely used to analyze the monotonically increasing or decreasing trends in climate change research [43,52-54]. It produces two important parameters: the slope magnitude (change per unit time) in a time series and the statistic $Z$ value that indicates the direction of the trend. Positive $Z$ values indicate increasing trends while negative ones show decreasing trends. The testing is carried out at a specific $\alpha$ significance levels. In this study, significance levels $\alpha=0.05$ and $\alpha=0.01$ were used. In addition, the arithmetic mean method by giving all the stations an equal weight was adopted in order to calculate the trend magnitudes in three sub-regions.

$$
S_{m, n}=\frac{1}{n} \sum_{i=1}^{n} S_{m, i}
$$

where $n$ is the sum of stations in region $m, S_{m, i}$ is the magnitude of station $i$ in region $m$, and $S_{m, n}$ is the regional mean magnitude in the region $m$.

\subsection{Correlation Analysis}

The ACPs indices (ENSO, NAO, AO, PDO, and IOD) were used to evaluate the influences of the ACPs on the temperature and precipitation extremes in the YRB. Statistically significant correlations between the climatic extremes and the ACPs indices were obtained by the Poisson regression model and the $\mathrm{F}$ value was used to determine the significance level.

\section{Results}

\subsection{Variation of the Extreme Precipitation Indices}

The variation of trends for the extreme precipitation indices is presented in Figure 2. In addition, the trends of the extreme precipitation indices in the whole YRB and three sub-regions are shown in Table 2. The spatial trends for consecutive dry days (CDD) showed that $68.2 \%$ of stations demonstrated decreasing trends (Figure 2a). An increasing trend was identified for $24.2 \%$ of stations, these were distributed in the middle and lower reaches of the research area. The trend magnitudes from these stations ranged from -8.8 to $2.35 \mathrm{~d} /$ decade, with only five stations $(7.6 \%)$ having significant negative trends at the 0.01 confidence level (Table 2, Figure 2a). It should be noted that significant negative trends were identified for the regional average series of CDD in the upper region, indicating that precipitation increased during the past decades. Approximately $15.2 \%$ of the stations exhibited increasing trends in the number of heavy precipitation days (R10mm), and for $3 \%$ of the stations, this increase was significant. The spatial distribution of R10mm showed that $25.8 \%$ of stations recorded a decreasing trend (Table 2), and these stations were located in the southeastern parts of the YRB (Figure $2 \mathrm{~b}$ ). More than $50 \%$ of stations recorded a stationary trend for R10mm. Similar to R10mm, only one station showed a significant negative trend in the number of very heavy precipitation days (R25mm). The changes of R25mm were not obvious, and although there was an ascending tendency, the change was very small. Stations with no identifiable trends were generally scattered across the whole YRB (Figure 2c). In general, the trend magnitudes in R10mm and R25mm were 0.025 and 0.033 $\mathrm{d} /$ decade, respectively; however, neither result was significant (Table 2). Across the whole of the YRB, very wet day precipitation (R95p) and extremely wet day precipitation (R99p) increased over the investigation period, with an average magnitude of 0.65 and $0.075 \mathrm{~mm} /$ decade, respectively (Table 2). Results for R95p showed that $39.4 \%$ of stations recorded increasing trends and $47 \%$ of stations showed decreasing trends, ranging from -13.72 to $8.8 \mathrm{~mm} /$ decade (Figure 2d). However, only two of these stations were significant at the $95 \%$ confidence level (Table 2). As for R99p, 97\% of stations located in the whole area identified no trend (Figure 2e), which indicates that the precipitation intensity was 
not obviously enhanced during 1960-2017. Maximum 1-day precipitation (RX1day) and maximum 5-day precipitation (RX5day) decreased from 1960 to 2017, by -0.29 and $0.46 \mathrm{~mm} /$ decade, respectively, but only $1.5 \%$ of stations showed significant increases at the 0.01 level (Figure 2f,g). For RX1day and RX5day, the proportion of stations with negative trends for these indices was $53 \%, 59.1 \%$, respectively, and the proportion of stations with positive trends for these indices was $47 \%$ and $40.9 \%$, respectively (Table 2). Although the numbers of stations showing decreasing trends for RX1day and RX5day are similar, the spatial characteristics of insignificant stations are different. The simple daily intensity index (SDII) exhibited an increase of $0.064 \mathrm{~mm} /$ day/decade over 1960-2017. Approximately $77.3 \%$ of stations with an increasing SDII trend were in the middle and lower reaches of the YRB (Figure $2 \mathrm{~h}$ ). Therefore, regional average series of SDII in the upper, middle, lower, and whole regions showed positive trends.

Overall, for all the precipitation indices, only a few stations were characterized by a significant increasing or decreasing extreme precipitation anomaly. The intensity of precipitation may have been strengthened, and the duration of extreme rainfall events appears to have been reduced; therefore, the heavy precipitation outbreaks tended to be increasingly shorter during 1960-2017 in the YRB.
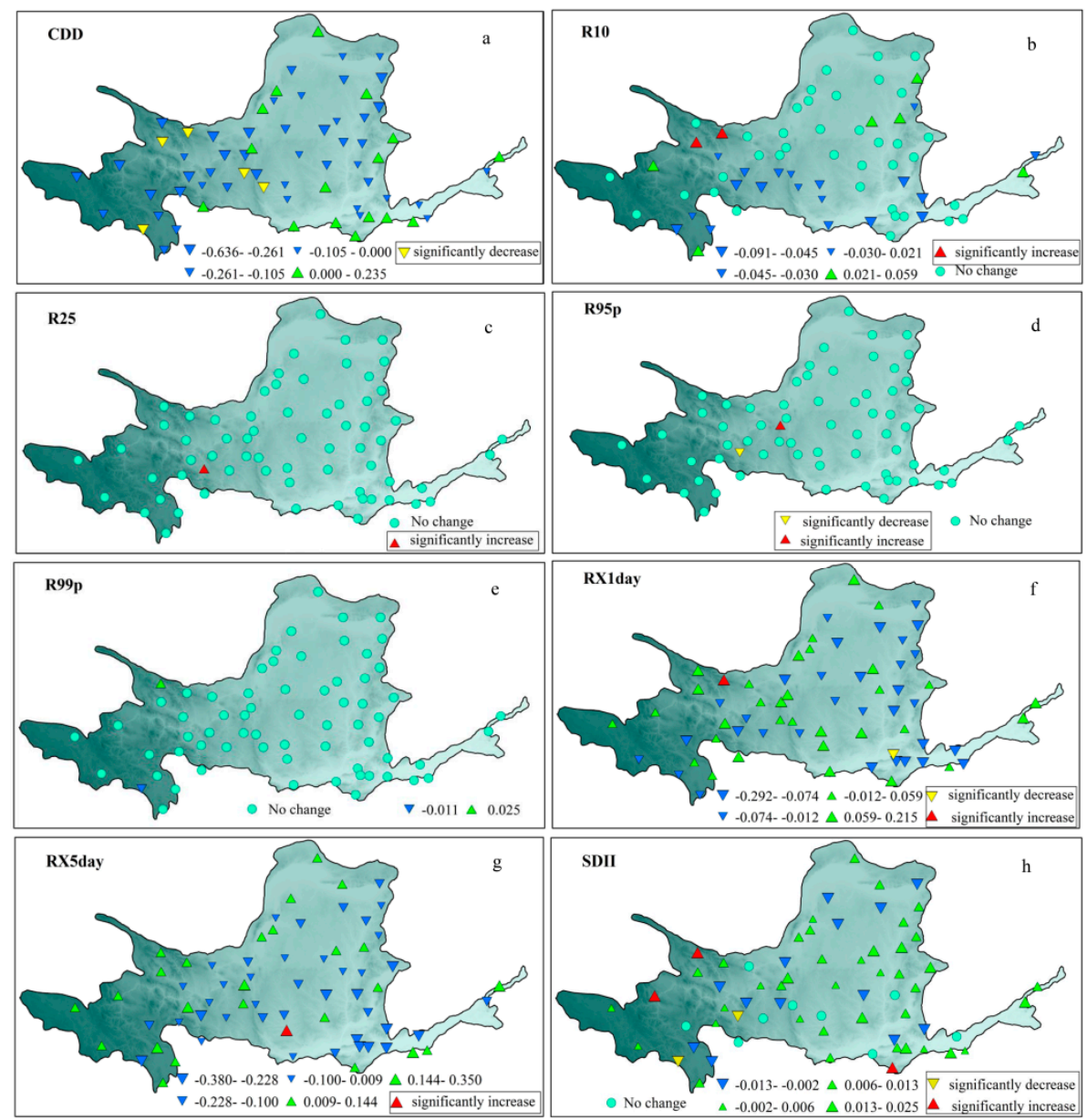

Figure 2. Interannual variation of precipitation extreme indices in the Yellow River basin (YRB) during 1960-2017. 
Table 2. Percentage of stations with positive (significant at the 0.01 level), negative (significant at the 0.01 level), and stationary trends for the trend test in annual extreme precipitation indices during 1960-2017.

\begin{tabular}{ccccccccc}
\hline Index & YRB & Range & Positive & Negative & Stationary & Upper & Middle & Lower \\
\hline CDD & -0.267 & $-0.880-0.235$ & $24.2 \%$ & $68.2 \%(7.6 \%)$ & $7.6 \%$ & -0.287 ** & -0.090 & -0.077 \\
R10mm & 0.003 & $-0.091-0.068$ & $15.2 \%(3 \%)$ & $25.8 \%$ & $59.1 \%$ & 0.005 & -0.001 & -0.001 \\
R25mm & 0.003 & $-0.029-0.000$ & 0 & $1.5 \%(1.5 \%)$ & $98.5 \%$ & 0.000 & 0.003 & 0.000 \\
R95p & 0.065 & $-1.372-0.880$ & $39.4 \%(1.5 \%)$ & $47 \%(1.5 \%)$ & $13.6 \%$ & -0.022 & -0.033 & -0.044 \\
R99p & 0.008 & $-0.011-0.025$ & $1.5 \%$ & $1.5 \%$ & $97 \%$ & 0.048 & -0.046 & 0.004 \\
RX1day & -0.029 & $-0.292-0.215$ & $47 \%(1.5 \%)$ & $53 \%$ & 0 & 0.012 & -0.043 & 0.019 \\
RX5day & -0.046 & $-0.380-0.410$ & $40.9 \%(1.5 \%)$ & $59.1 \%$ & 0 & -0.008 & -0.041 & -0.041 \\
SDII & 0.006 & $-0.020-0.029$ & $63.6 \%(4.5 \%)$ & $22.7 \%(3.0 \%)$ & $13.6 \%$ & 0.002 & 0.006 & 0.007 \\
\hline
\end{tabular}

Note: ** indicates significant values at the 0.01 confidence level. YRB denotes the trends in the whole YRB, stationary denotes that there are no trends for the stations accounting for this proportion, and zero denotes that there are no trends for the stations.

\subsection{Variation of the Extreme Temperature Indices}

Figure 3 presents the spatial change of the $\mathrm{M}-\mathrm{K}$ test for extreme temperature indices at 66 meteorological stations during 1960-2017 in the YRB. The percentage of stations with upward and downward trends, and the regional trends for eight indices in three regions as well as the whole YRB are shown in Table 3. For the period 1960-2017, the trends of frost days (FD) showed a strong pattern of decreasing trends, and $92.4 \%$ out of the $93.9 \%$ decreasing stations showed significance at the 0.01 level (Figure $3 \mathrm{a}$ and Table 3). The regional trends for FD were all significant in the whole region, ranging from $-3.72 \mathrm{~d} /$ decade in the upper reaches to $-4.11 \mathrm{~d} /$ decade in the lower reaches. Alexander et al. [55] concluded that the largest significant change for FD appeared in the Tibet Plateau, which was consistent with the results in this study. Conversely, the number of summer days (SU) showed a significant increasing trend of $2.16 \mathrm{~d} /$ decade over the whole YRB. The percentage of stations with significant positive trends was $71.2 \%$. Geographically, the greatest magnitude for SU was found in the middle reaches at a rate of $2.56 \mathrm{~d} /$ decade (Figure $3 \mathrm{~b}$ and Table 3 ), and ten stations had no trends in the upper reaches due to the high elevations and low temperatures. For the YRB as a whole, the warmest days (TXx) significantly increased with a trend of $0.18^{\circ} \mathrm{C} /$ decade, with approximately $45.5 \%$ of stations showing significant increasing trends (Table 3). Stations in the upper reaches had the largest magnitude of $0.34^{\circ} \mathrm{C} /$ decade for $\mathrm{TXx}$, indicating more rapid warming in this region. The reduction was distributed sporadically in the middle and lower reaches of the YRB (Figure 3c). The coldest nights (TNn) had a significant warming trend with a magnitude of $0.45^{\circ} \mathrm{C} /$ decade (Table 3). The main reason is a faster increase in minimum temperature than maximum temperature. TNn displayed very similar patterns to TXx, but wirh greater magnitudes in all regions. The smallest trend for TNn was found in the middle reaches of the YRB, where an insignificant trend of $0.43{ }^{\circ} \mathrm{C} /$ decade was observed (Figure $3 \mathrm{~d}$ and Table 3). Statistically, warming trends were detected in the number of the cold days (TX10p) and cold nights (TN10p) at an $\alpha=0.01$ level. For TX10p, the whole YRB exhibited a significant decreasing trend of -2.0 day/decade, and $92.4 \%$ of stations showed significant negative trends. Greater magnitudes occurred in the upper and middle reaches of the YRB with trends of -2.06 and -2.12 day/decade, respectively (Figure $3 e$ and Table 3). For the trend per decade of TN10p, approximately $92.4 \%$ of the total stations were featured by positive trends, and all of them passed the significance test at the 0.01 level (Table 3). The TN10p had a more pronounced warming trend than TX10p, which can be reflected not only by the trend magnitude of the regional series of TX10p and TN10p but also by the comparison of their spatial patterns (Figure 3e,f). The warm days (TX90p) and warm nights (TN90p) presented significant increasing trends with corresponding rates of change of 2.29 and 3.32 days/decade, respectively (Table 3). As for TX90p, significant upward trends mainly occurred in the upper regions, whereas the $7.6 \%$ of stations with decreasing trends for TX90p mainly occurred in the lower regions of the YRB (Figure 3g). Spatially, the increasing trend of TN90 was apparent and significant but did not include any stations located in the lower regions (Figure $3 \mathrm{~h}$ ). 
TN90p and TX90p all experienced significant warming. However, the warming was more pronounced in TN90P, showing greater warming at nighttime than daytime.

On average, the trend magnitudes for cold extremes were larger than those for warm extremes. For example, the trend magnitudes in TN90p ( -3.3 days/decade) were more than that of TX90p (2.3 days/decade). Similarly, the changes of regional trends in FD ( -3.72 days/decade) were higher than SU (2.16 days/decade) from 1960 to 2017. Therefore, these results also reflected the instability and complexity of climate change in a large river basin under the background of global change. Such findings were confirmed by many studies of the Yangtze River [18] and of Southwest China [56]. Additionally, trends analysis of temperature extremes revealed significant warming over the whole YRB during 1960-2017, while precipitation extremes did not show significant variation trends.

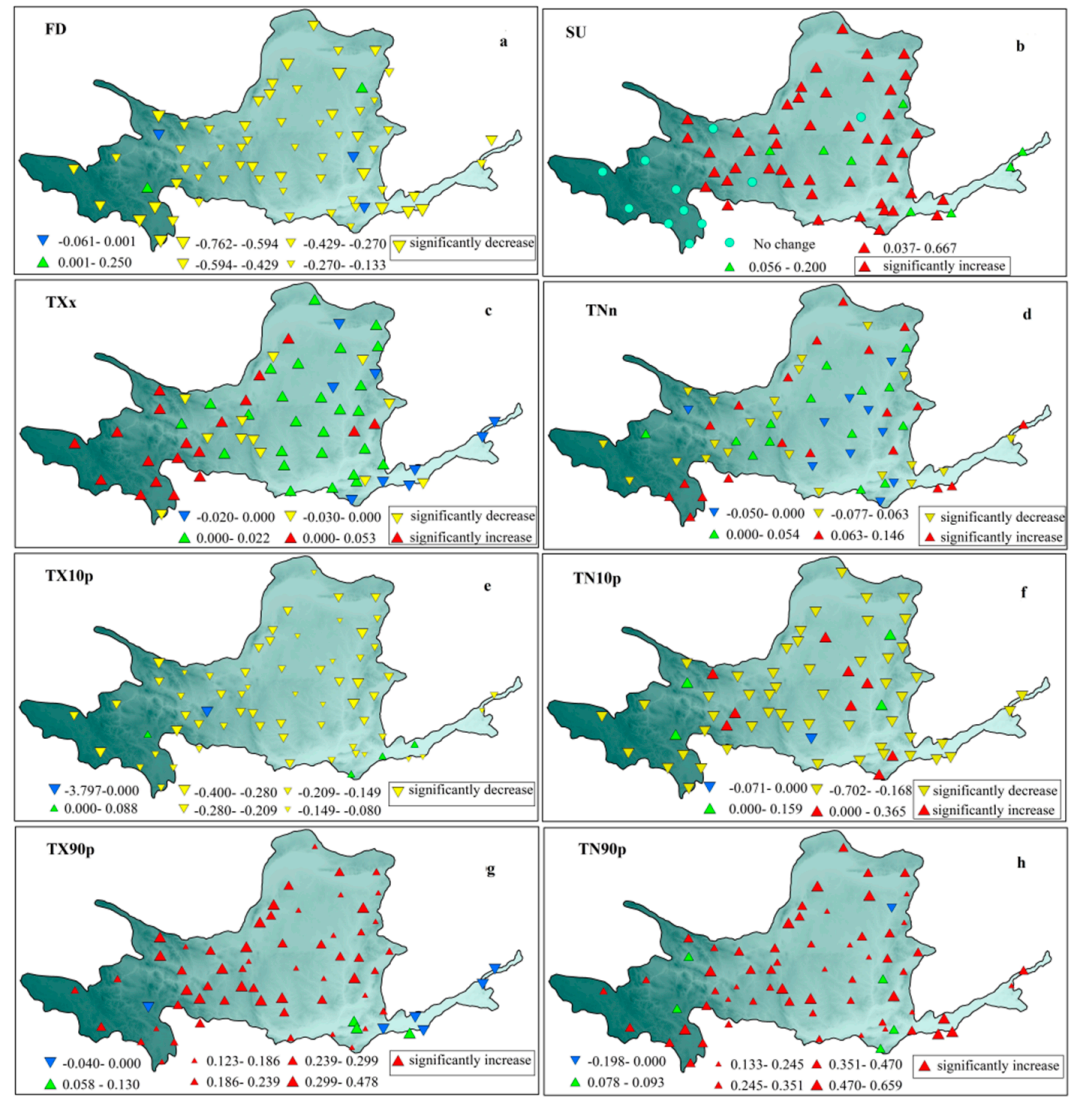

Figure 3. The spatial change of temperature extreme indices in the Yellow River basin (YRB) during 1960-2017.

Table 3. Percentage of stations with positive (significant at the 0.01 level), negative (significant at the 0.01 level), and stationary trends for the trend test in annual extreme temperature indices during 1960-2017.

\begin{tabular}{|c|c|c|c|c|c|c|c|c|}
\hline Index & YRB & Range & Positive & Negative & Stationary & Upper & Middle & Lower \\
\hline FD & $-0.372 * *$ & $-0.762-0.250$ & $4.5 \%$ & $93.9 \%(92.4 \%)$ & $1.5 \%$ & $-0.372 * *$ & $-0.381 * *$ & $-0.411^{* *}$ \\
\hline SU & $0.216^{* *}$ & $0.000-0.667$ & $83.3 \%(71.2 \%)$ & 0 & $16.7 \%$ & $0.158^{* *}$ & $0.256^{* *}$ & $0.208^{* *}$ \\
\hline TN10p & $-0.359 * *$ & $-0.702-0.365$ & $7.6 \%$ & $92.4 \%(92.4 \%)$ & 0 & $-0.361 * *$ & $-0.344^{* *}$ & $-0.337 * *$ \\
\hline TN90p & $0.332 * *$ & $-0.198-0.659$ & $97 \%(90.9 \%)$ & $3 \%$ & 0 & $0.345^{* *}$ & $0.340 * *$ & $0.334^{* *}$ \\
\hline TNn & $0.045^{* *}$ & $-0.077-0.146$ & $86.4 \%(62.1 \%)$ & $9.1 \%(3 \%)$ & $4.5 \%$ & 0.052 ** & $0.043^{* *}$ & $0.044^{* *}$ \\
\hline TXx & 0.018 * & $-0.029-0.053$ & $84.8 \%(45.5 \%)$ & $12.1 \%(1.5 \%)$ & $3 \%$ & $0.034^{* *}$ & $0.014^{*}$ & 0.002 \\
\hline TX10p & $-0.200^{* *}$ & $-3.797-0.088$ & $1.5 \%$ & $98.5 \%(92.4 \%)$ & 0 & $-0.206^{* *}$ & $-0.212 * *$ & $-0.142 * *$ \\
\hline TX90p & $0.229^{* *}$ & $-0.040-0.479$ & $90.9 \%(86.4 \%)$ & $9.1 \%$ & 0 & $0.258^{* *}$ & $0.239 * *$ & $0.116^{*}$ \\
\hline
\end{tabular}

Note: ${ }^{*}$ and ${ }^{* *}$ indicate significant values at the 0.05 and 0.01 confidence level, respectively. YRB denotes the trends in the whole YRB, stationary denotes that there are no trends for the stations accounting for this proportion, and zero denotes that there are no trends for the stations. 


\subsection{Relationship between the Extreme Climatic Indices and the ACPS}

Figures 4-8 show the correlation between extreme climatic indices and the ACP indices of ENSO, $\mathrm{AO}, \mathrm{NAO}, \mathrm{PDO}$, and IOD. However, the correlation between the precipitation extremes and the ACPs shows that ACPs are not clearly associated with the precipitation extremes (data not shown) and we do not explore that in this article. Generally, only a few stations exhibited a significant correlation with ENSO, AO, NAO, PDO, and IOD indices. However, some spatial characteristics still can be identified. ENSO exhibited a cluster of significantly negative correlations for FD and TX10p in the middle and lower regions of the YRB. Obviously, the correlation between ENSO indices with SU, TNn, and TX90p was dominated by significantly positive values for stations in the lower reaches and northern area of the YRB (Figure 4). For AO, it mainly exhibited a significantly negative correlation for FD and TN10p in most areas, and for TXx and TX90p in the lower reaches of the YRB. Only a few stations, which are sporadically distributed in the YRB, showed significantly positive correlation with TN90p and TNn (Figure 5). Figure 6 shows significant negative correlations between these temperature extreme indices (FD, TN10P, and TXx) and NAO indices, and significant positive correlations between TNn and NAO in some parts of the YRB. The TN10p values, which had significant negative correlations with PDO indices, are sporadically distributed in some areas of the YRB, while the TNn values, which had significant positive correlations with PDO indices, tend to a cluster in the north of the YRB (Figure 7). For IOD, the few stations that exhibited a significantly negative correlation with SU, TNn, and TX90p are sporadically distributed in northern and eastern parts of the YRB (Figure 8).

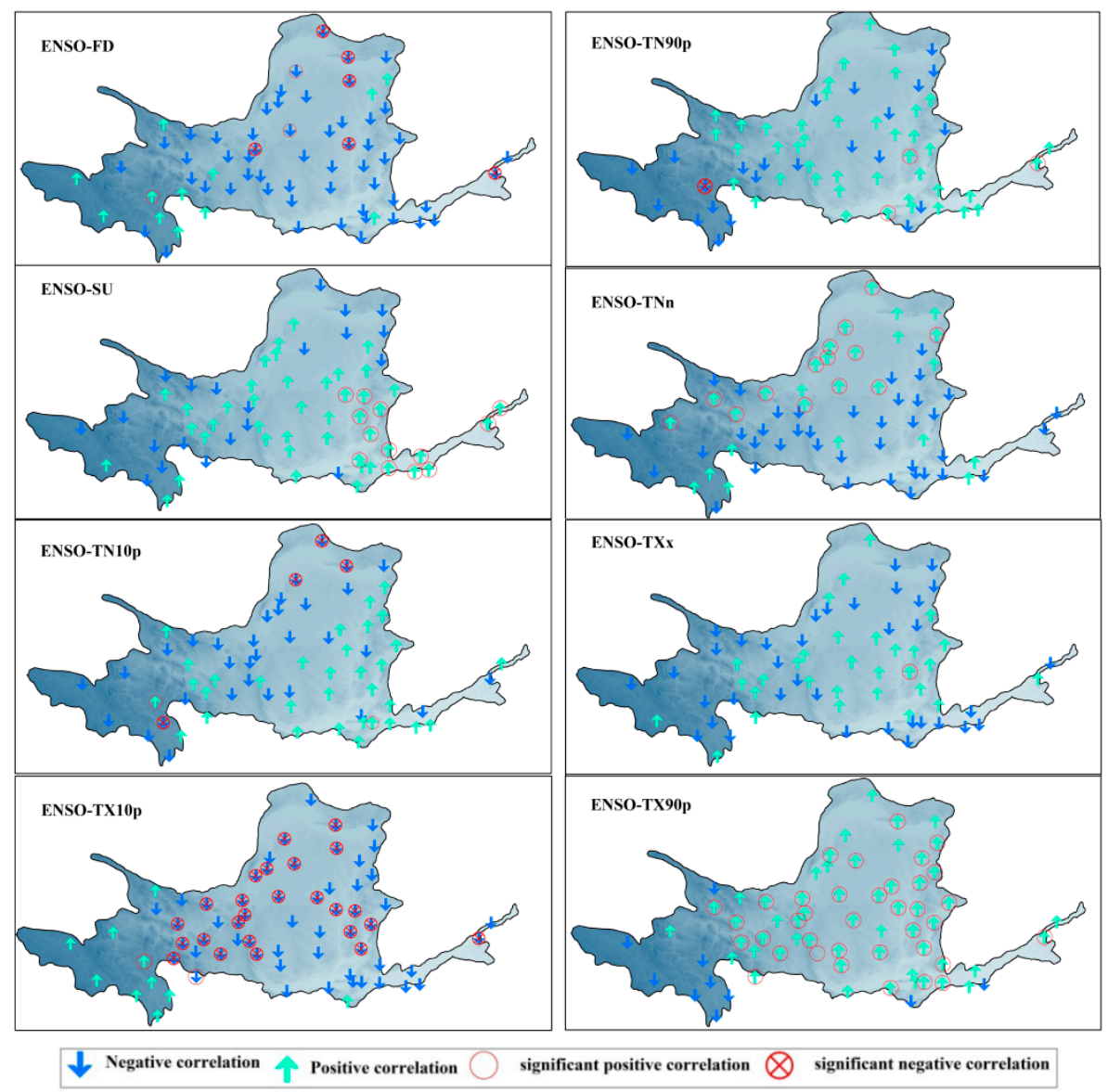

Figure 4. The potential connection between temperature extremes and the El Niño-Southern Oscillation (ENSO). 


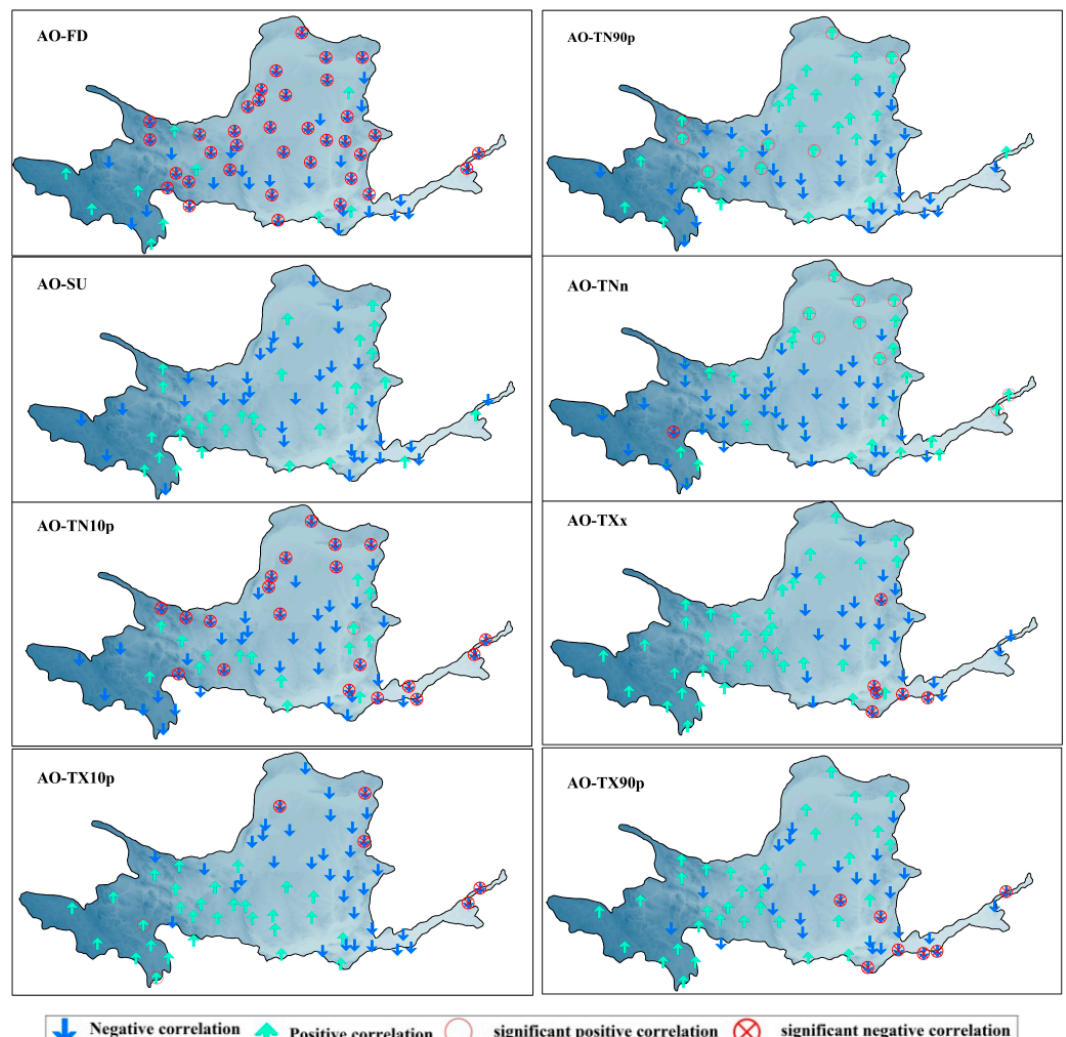

Figure 5. The potential connection between temperature extremes and the Arctic Oscillation (AO).

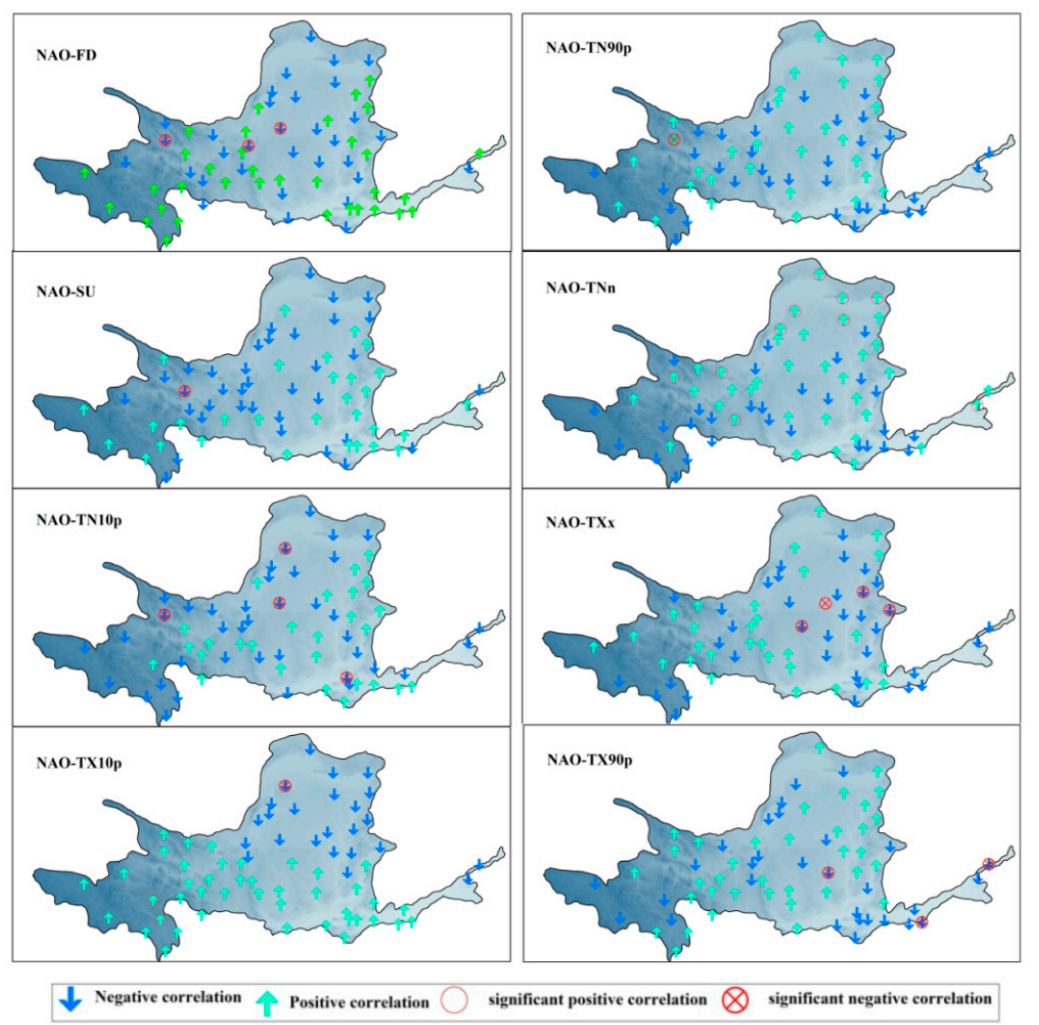

Figure 6. The potential connection between temperature extremes and the North Atlantic Oscillation (NAO). 

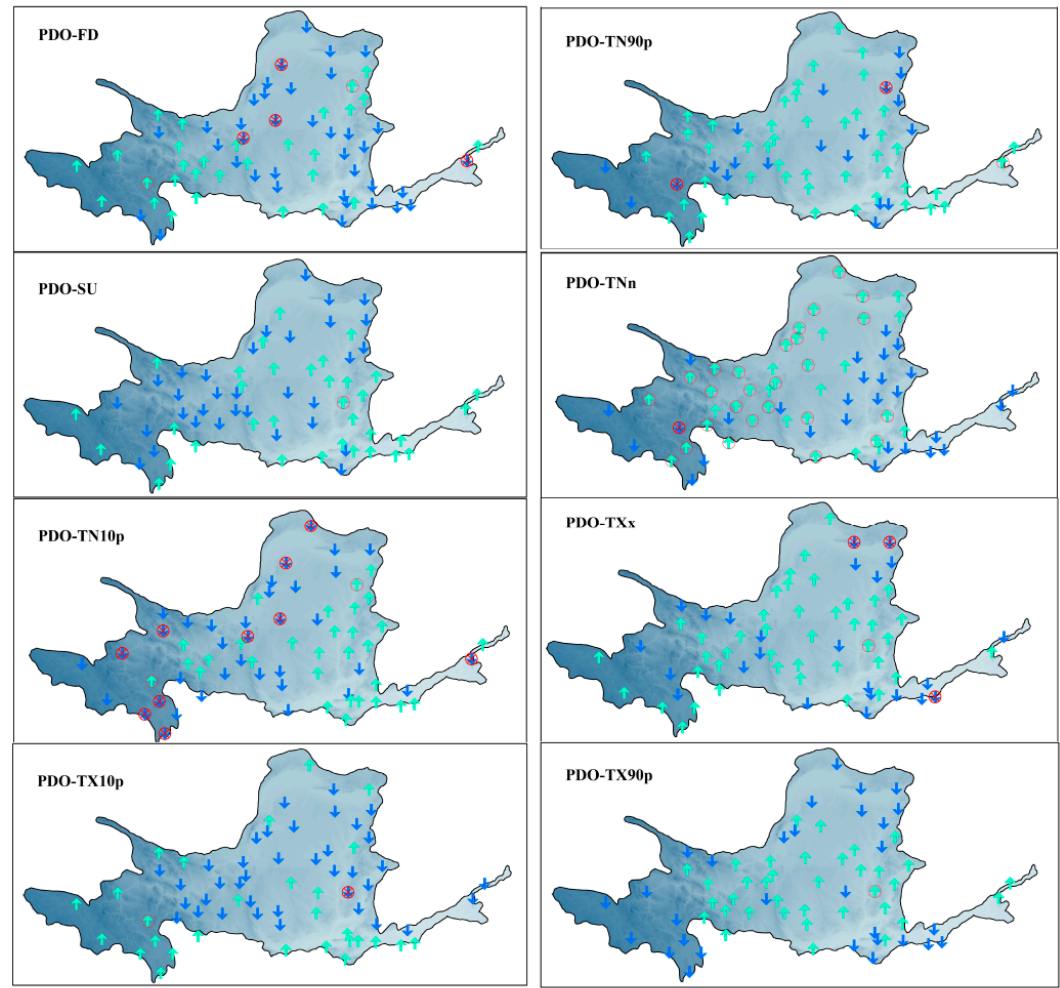

$\downarrow$ Negative correlation $\uparrow$ Positive correlation $\bigcirc$ significant positive correlation $\otimes$ significant negative correlation

Figure 7. The potential connection between temperature extremes and the Pacific Decadal Oscillation (PDO).

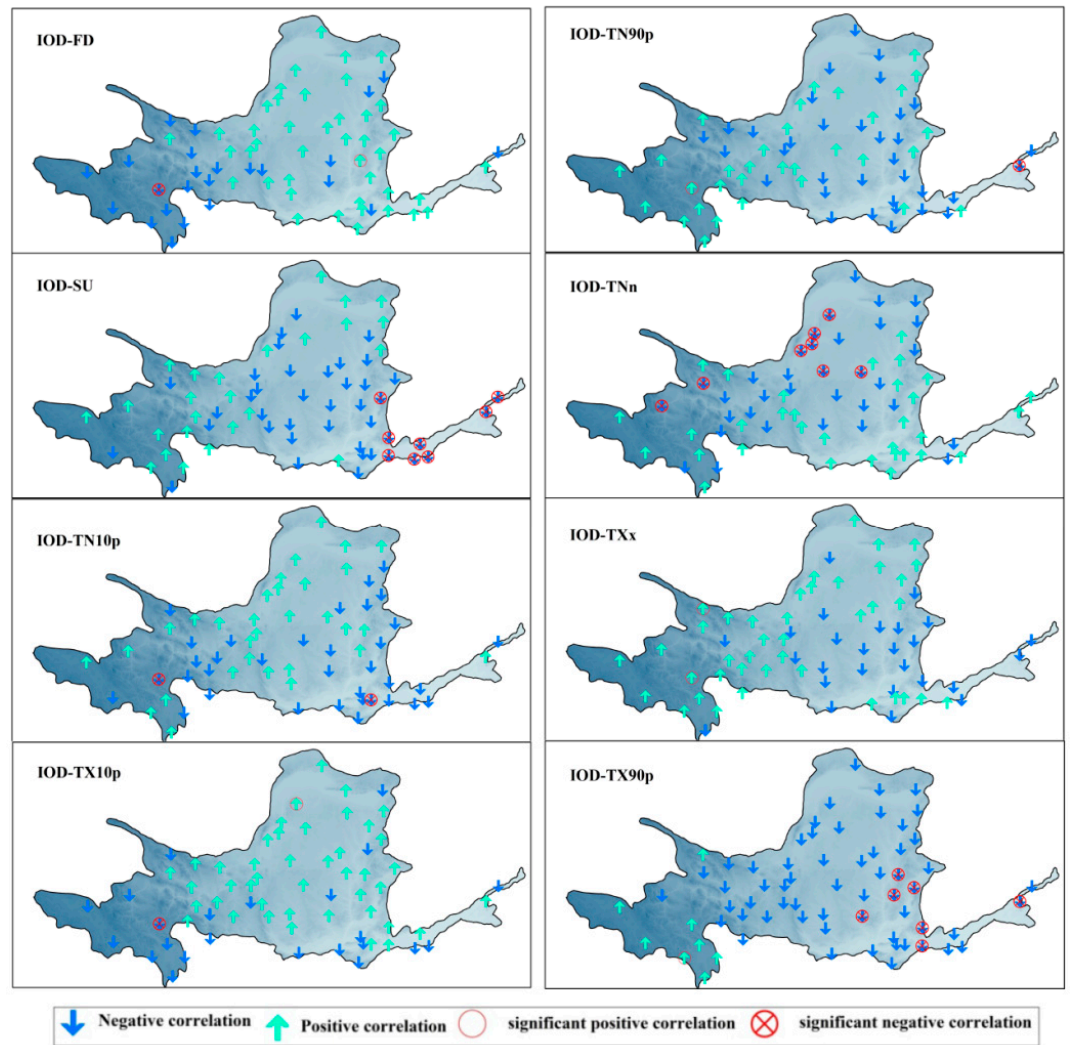

Figure 8. The potential connection between temperature extremes and the Indian Ocean Dipole (IOD). 


\section{Discussion}

In the present study, a total of 16 indices that represent climatic extreme events were calculated by using daily precipitation and maximum and minimum temperature data from 66 stations from 1960 to 2017 and analyzed thoroughly for characteristic variation trends and their connections to the ACPs (ENSO, AO, NAO, PDO and IOD) over the entire YRB.

Our study concluded that there were no significant change trends in precipitation extremes during 1960-2017 in this basin. It should be noted that the significant decreasing trend ( -2.88 days/decade) of CDD was observed in the upper regions (Table 2). In addition, both the SDII and heavy precipitation events (e.g., R10mm and R25mm) had slightly increasing trends over the investigation period. Recently, precipitation changes were associated with latitude and elevation in some studies that found increased precipitation frequency in higher altitudes and a decreasing trend at lower altitudes in the southwest of China [53,56]. The Intergovernmental Panel on Climate Change (IPCC) [30] also pointed out that increases in the amount of precipitation were very likely at high latitudes while declines were likely in most subtropical land regions. These changes are consistent with previous studies in other parts of China $[4,19,26,37,57]$.

In this study, warming trends were observed in the indices of TXx and TNn, but the trend magnitude of TNn $\left(0.45^{\circ} \mathrm{C} /\right.$ decade $)$ was much larger than that of $\mathrm{TXx}\left(0.18^{\circ} \mathrm{C} /\right.$ decade $)$. This asymmetry between the magnitudes of changes in TNn and TXX agrees with an earlier global study [55] and a regional study [58]. The trend magnitude of TNn in the YRB is lower than the average value of China and smaller than that on the global scale $\left(0.71{ }^{\circ} \mathrm{C} /\right.$ decade) [55], but larger than that in the Yangtze River Basin $\left(0.42{ }^{\circ} \mathrm{C} /\right.$ decade) [18], which is the longest river in China. In addition, we found that the occurrence of TX10p and TN10p significantly decreased, while the occurrence of TX90p and TN90p exhibited statistically significant increases during 1960-2017. These results were generally consistent with Li et al. [56] and Guan et al. [18]. Our results also revealed that the spatial pattern of changes in frequency and magnitude for climatic extremes presents obvious spatial differences. These results were in line with previous studies, for example, Tian et al. [59] found that the annual precipitation did not show a significant trend and the annual mean temperature had a significant increasing trend over three major river basins of China (Yellow River, Yangtze River, and Pearl River) in the last few decades. Taken together, the increasing trends of extreme temperature indices (SU, TXx, TNn, TX90p, and TN90p) and decreasing trends of others (FD, TX10p, and TN10p) obtained in this study illustrate that there was more drought in the YRB in the last six decades despite a slight increase in the magnitude and frequency of heavy precipitation events.

Finally, we found that ENSO, AO, NAO, and PDO indices exhibited significant positive correlation for the TNn, and significant negative correlation for TN10p only at a few stations. ENSO indices exhibited significant positive correlation for the TX90p in most stations of the whole YRB, but AO and IOD indices showed significant negative correlation for TX90p in the lower reach of the YRB (Figures 4-7). Additionally, we found that those ACP indices exhibited positive correlation for the increasing trends of most extreme temperature indices, but negative correlation for those that showed decreasing trends. We conclude that the atmospheric circulation patterns have enhanced the gap of the maximum and minimum temperature and were the physical mechanisms for the extreme cold/warm events in the past decades. These results are consistent with previous studies in most parts of East Asia [38,43,45,60-62], including the YRB of China [4,63].

\section{Conclusions}

Based on the above analysis and discussions, the important conclusions can be summarized as follows.

For all the precipitation extreme indices, only a few stations were characterized by significantly increasing or decreasing extreme precipitation anomalies during 1960-2017 in the YRB. Nonsignificant increasing trends were detected for the most extreme indices including heavy precipitation and heaviest precipitation days, very wet and extremely wet day precipitation, and simple precipitation 
intensity index. However, nonsignificant decreasing trends were maximum 1-day and 5-day precipitation, and the consecutive dry days (e.g., CDD) exhibited a prominent significant decreasing trend ( -2.88 days/decade) in the upper regions of the YRB. In addition, both precipitation intensity (e.g., SDII) and heavy precipitation magnitudes and frequencies (e.g., R95p, R10mm, and R25mm) increased slightly over the investigation period. These results reveal that the precipitation intensity may have been strengthened, and the duration of extreme rainfall events appears to have been reduced. Therefore, the heavy rainfall events tended to be increasingly shorter during 1960-2017 in the YRB.

All the temperature extreme indices revealed widespread significant changes associated with global warming in most regions of the YRB during the study period. For TNn, TN10p, TN90p, and FD, the warming trends were of greater magnitude than those of the indices TXx, TX10p, and TX90. For the vast majority of stations, significant increases in TX90p, TN90p, and SU, but significant decreases in TN10p, FD, and TX10p were observed over the entire study period.

In this study, we found that the relationship between the ACPs (ENSO, AO, NAO, PDO, and IOD) and precipitation extremes showed that the ACPs are not clearly associated with precipitation extremes. However, the relationship between the ACPs and temperature extremes shows that the influence of the ENSO and $\mathrm{AO}$ on temperature extremes outweighs that of the NAO, IOD, and PDO for most extreme indices in the YRB. The ENSO, AO, NAO, and PDO indices exhibited significant positive correlation for TNn, but significant negative correlation for TN10p. Therefore, the relationship between the ACPs and climatic extremes demonstrates that the influence of the ACPs on temperature extremes outweighs that on precipitation extremes in the YRB. We can conclude that the change of the ACPs is an important physical mechanism affecting the heat and moisture transportation in this region. Admittedly, the changes of climatic extremes are driven by the broader context of climate change; we did not make more detailed assessments of the physical mechanisms between the ACPs and climatic extremes in this paper, and further work needs to be carried out to clarify this issue.

Author Contributions: Conceptualization, X.D. and S.Z.; Data curation, X.D., L.J., Z.Z., and Y.L.; Formal analysis, X.D., Z.Z., and Y.L.; Funding acquisition, X.D. and J.Z.; Methodology, X.D. and S.Z.; Software, X.D., J.Z., and L.J.; Validation, S.Z. and J.C.; Visualization, X.D.; Writing—original draft, X.D.; Writing—review and editing, S.Z., J.Z., and J.C.

Funding: This research was funded by the National Key Research and Development Program of China (Grant Number: 2018YFD0502401), the National Natural Science Foundation of China (Grant Number: 31870435 and 41761047), and the Sci \& Tech. Department of Northwest Normal University, China (Grant Number: NWNU-LKQN-18-1).

Conflicts of Interest: The authors declare no conflict of interest.

\section{References}

1. Kunkel, K.E.; Pielke, R.A.; Changnon, S.A. Temporal fluctuations in weather and climate extremes that cause economic and human health impacts: A review. Bull. Am. Meteorol. Soc. 1999, 80, 1077-1098. [CrossRef]

2. Easterling, D.R.; Evans, J.L.; Groisman, P.Y.; Karl, T.R.; Kunkel, K.E.; Ambenje, P. Observed variability and trends in extreme climate events: A brief review. Bull. Am. Meteorol. Soc. 2000,81, 417-425. [CrossRef]

3. Wuebbles, D.; Meehl, G.; Hayhoe, K.; Karl, T.R.; Kunkel, K.; Santer, B.; Fu, R. CMIP5 climate model analyses: Climate extremes in the United States. Bull. Am. Meteorol. Soc. 2014, 95, 571-583. [CrossRef]

4. Gao, T.; Wang, H.L. Trends in precipitation extremes over the yellow river basin in north china: Changing properties and causes. Hydrol. Process. 2017, 31, 2412-2428. [CrossRef]

5. Cinco, T.A.; Guzman, R.G.D.; Hilario, F.D.; Wilson, D.M. Long-term trends and extremes in observed daily precipitation and near surface air temperature in the Philippines for the period 1951-2010. Atmos. Res. 2015, 14, 12-26. [CrossRef]

6. Katz, R.W.; Brown, B.G. Extreme events in a changing climate: Variability is more important than averages. Clim. Chang. 1992, 21, 289-302. [CrossRef]

7. Plummer, N.; Salinger, M.J.; Nicholis, N.; Suppiah, R.; Hennessy, K.J.; Leighton, R.M.; Trewin, B.; Page, C.M.; Lough, J.M. Changes in climate extremes over the Australian region and New Zealand during the twentieth century. Clim. Chang. 1999, 42, 183-202. [CrossRef] 
8. Ingram, W. Extreme precipitation: Increases all round. Nat. Clim. Chang. 2016, 6, 443-444. [CrossRef]

9. IPCC. Climate change 2013: The physical science basis. In Working Group I Contribution to the Intergovernmental Panel on Climate Change Fifth Assessment Report (AR5)_Changes to the Underlying Scientifc/Technical Assessment; Cambridge University Press: Cambridge, UK, 2013.

10. Zhang, X.Z.; Li, P.; Li, D.S. spatiotemporal variations of precipitation in the southern part of the Heihe river basin (China), 1984-2014. Water 2018, 10, 410. [CrossRef]

11. Donat, M.G.; Lowry, A.L.; Alexander, L.V.; O'Gorman, P.A.; Maher, N. More extreme precipitation in the world's dry and wet regions. Nat. Clim. Chang. 2016, 6, 508-513. [CrossRef]

12. Zhang, Y.G.; Su, F.G.; Hao, Z.C.; Xu, C.Y.; Yu, Z.B.; Wang, L.; Tong, K. Impact of projected climate change on the hydrology in the headwaters of the Yellow River basin. Hydrol. Process. 2015, 29, 4379-4397. [CrossRef]

13. Ozer, P.; Mahamoud, A. Recent extreme precipitation and temperature changes in Djibouti city (1966-2011). J. Climatol. 2013, 2013, 1-8. [CrossRef]

14. Diffenbaugh, N.; Pal, J.; Trapp, R.; Giorgi, F. Fine-scale processes regulate the response of extreme events to global climate change. Proc. Natl. Acad. Sci. USA 2005, 102, 15774-15778. [CrossRef] [PubMed]

15. Wang, H.; Chen, Y.; Xun, S.; Lai, D.; Fan, Y.; Li, Z. Changes in daily climate extremes in the arid area of northwestern China. Theor. Appl. Climatol. 2013, 112, 15-28. [CrossRef]

16. Liu, W.L.; Zhang, M.J.; Wang, S.J.; Wang, B.L.; Li, F.; Che, Y.J. Changes in precipitation extremes over Shaanxi province, northwestern China, during 1960-2011. Quatern. Int. 2013, 313-314, 118-129. [CrossRef]

17. Gu, X.H.; Zhang, Q.; Singh, V.P.; Shi, P.J. Changes in magnitude and frequency of heavy precipitation across China and its potential links to summer temperature. J. Hydrol. 2017, 547, 718-731. [CrossRef]

18. Guan, Y.H.; Zhang, X.C.; Zheng, F.L.; Wang, B. Trends and variability of daily temperature extremes during 1960-2012 in the Yangtze River basin, China. Glob. Planet. Chang. 2015, 124, 79-94. [CrossRef]

19. Wang, S.J.; Zhang, M.J.; Sun, M.P.; Wang, B.L.; Li, X.F. Changes in precipitation extremes in alpine areas of the Chinese Tianshan Mountains, central Asia, 1961-2011. Quatern. Int. 2013, 311, 97-107. [CrossRef]

20. Li, C.X.; Tian, Q.H.; Yu, R.; Zhou, B.Q.; Xia, J.J.; Burke, C.; Dong, B.W. Attribution of extreme precipitation in the lower reaches of the Yangtze River during May 2016. Environ. Res. Lett. 2018, 13, 14-15. [CrossRef]

21. Zhang, X.B.; Aguilar, E.; Sensoy, S. Trends in Middle East climate extreme indices from 1950 to 2003. J. Geophys. Res. 2005, 110, 3159-3172. [CrossRef]

22. New, M.; Hewitson, B.; Stephenson, D.B.; Tsiga, A.; Kruger, A.; Manhique, A.; Gomez, B.; Coelho, C.A.S.; Masisi, D.N.; Kululanga, E.; et al. Evidence of trends in daily climate extremes over Southern and West Africa. J. Geophys. Res. Atmos. 2006, 111, 3007-3021. [CrossRef]

23. Perkins, S.E.; Moise, A.; Whetton, P.; Katzfey, J. Regional changes of climate extremes over Australia-a comparison of regional dynamical downscaling and global climate model simulations. Int. J. Climatol. 2014, 34, 3456-3478. [CrossRef]

24. Wang, H.J.; Pan, Y.P.; Chen, Y.N.; Ye, Z.W. Linear trend and abrupt changes of climate indices in the arid region of northwestern China. Atmos. Res. 2017, 196, 108-118. [CrossRef]

25. Kundzewicz, Z.W. Extreme weather events and their consequences. Pap. Glob. Chang. Igbp. 2016, $23,59-69$. [CrossRef]

26. Liu, Q.; Yang, Z.F.; Cui, B.S. Spatial and temporal variability of annual precipitation during 1961-2006 in Yellow River basin, China. J. Hydrol. 2008, 361, 330-338. [CrossRef]

27. Piao, S.; Ciais, P.; Huang, Y.; Shen, Z.; Peng, S.; Li, J.; Zhou, L.; Liu, H.; Ma, Y.; Ding, Y.; et al. The impacts of climate change on water resources and agriculture in China. Nature 2010, 467, 43-51. [CrossRef]

28. Zhao, F.F.; Xu, Z.X.; Huang, J.X.; Li, J.Y. Monotonic trend and abrupt changes for major climate variables in the headwater catchment of the Yellow River basin. Hydrol. Process. 2008, 22, 4587-4599. [CrossRef]

29. Yang, Z.F.; Liu, Q. Response of Streamflow to Climate Changes in the Yellow River Basin, China. J. Hydrometeorol. 2011, 12, 1113-1126. [CrossRef]

30. IPCC. Summary for Policymakers of Climate Change 2007, the Physical Science Basis. Contribution of Working Group I to the Fourth Assessment Report of the Intergovernmental Panel on Climate Change; Cambridge University Press: Cambridge, UK; New York, NY, USA, 2007.

31. Dong, Q.; Chen, X.; Chen, T.X. Characteristics and changes of extreme precipitation in the Yellow-Huaihe and Yangtze-Huaihe Rivers basins, China. J. Clim. 2011, 24, 3781-3795. [CrossRef] 
32. Irannezhad, M.; Chen, D.; Kløve, B.; Moradkhani, H. Analysing the variability and trends of precipitation extremes in Finland and their connection to atmospheric circulation patterns. Int. J. Climatol. 2017, 37, 1053-1066. [CrossRef]

33. Wibig, J.; Piotrowski, P. Impact of the air temperature and atmospheric circulation on extreme precipitation in Poland. Int. J. Climatol. 2018, 38, 4533-4549. [CrossRef]

34. Haylock, M.; Goodess, C. Interannual variability of European extreme winter rainfall and links with mean large-scale circulation. Int. J. Climatol. 2004, 24, 759-776. [CrossRef]

35. Toreti, A.; Xoplaki, E.; Maraun, D.; Kuglitsch, F.G.; Wanner, H.; Luterbacher, J. Characterisation of extreme winter precipitation in mediterranean coastal sites and associated anomalous atmospheric circulation patterns. Nat. Hazards Earth Syst. Sci. 2010, 10, 1037-1050. [CrossRef]

36. She, D.X.; Xia, J.; Zhang, D.; Ye, A.Z.; Sood, A. Regional extreme dry-spell frequency analysis using the L-moments method in the middle reaches of the Yellow River basin, China. Hydrol. Processes 2014, 28, 4694-4707. [CrossRef]

37. Liang, K.; Liu, S.; Bai, P.; Nie, R. The Yellow River basin becomes wetter or drier? The case as indicated by mean precipitation and extremes during 1961-2012. Theor. Appl. Climatol. 2015, 119, 701-722. [CrossRef]

38. Duan, W.L.; He, B.; Takara, K.; Luo, P.P.; Hu, M.C.; Nor, E.A.; Daniel, N. Changes of precipitation amounts and extremes over Japan between 1901 and 2012 and their connection to climate indices. Clim. Dynam. 2015, 45, 2273-2292. [CrossRef]

39. Rusticucci, M.; Barrucand, M.; Collazo, S. Temperature extremes in the Argentina central region and their monthly relationship with the mean circulation and ENSO phases. Int. J. Climatol. 2017, 37, 3003-3017. [CrossRef]

40. Hoerling, M.; Eischeid, J.; Perlwitz, J.; Quan, X.W.; Wolter, K.; Cheng, L.Y. Characterizing recent trends in U.S. heavy precipitation. J. Clim. 2016, 29, 2313-2332. [CrossRef]

41. Mallakpour, I.; Villarini, G. Investigating the relationship between the frequency of flooding over the central United States and large-scale climate. Adv. Water Resour. 2016, 92, 159-171. [CrossRef]

42. Yue, Y.; Shen, S.H.; Wang, Q. Trend and variability in droughts in northeast China based on the reconnaissance drought index. Water 2018, 10, 318. [CrossRef]

43. Deng, Y.; Jiang, W.G.; He, B.; Chen, Z.; Jia, K. Change in intensity and frequency of extreme precipitation and its possible teleconnection with large-scale climate index over the China from 1960 to 2015. J. Geophys. Res. Atmos. 2018, 123, 2068-2081. [CrossRef]

44. Rong, X.Y.; Zhang, R.H.; Li, T. Impacts of Atlantic sea surface temperature anomalies on Indo-East Asian summer monsoon-ENSO relationship. Chin. Sci. Bull. 2010, 55, 1397-1408. [CrossRef]

45. Xiao, M.Z.; Zhang, Q.; Singh, V.P. Influences of enso, nao, iod and pdo on seasonal precipitation regimes in the Yangtze River basin, China. Int. J. Climatol. 2015, 35, 3556-3567. [CrossRef]

46. Zhang, K.X.; Qian, X.Q.; Liu, P.X.; Xu, Y.H.; Cao, L.G.; Hao, Y.P. Variation characteristics and influences of climate factors on aridity index and its association with AO and ENSO in northern China from 1961 to 2012. Theore. Appl. Climatol. 2017, 130, 523-533. [CrossRef]

47. Wang, H.J.; Yang, Z.S.; Saito, Y.; Liu, J.P.; Sun, X.X. Interannual and seasonal variation of the Huanghe (Yellow River) water discharge over the past 50 years: Connections to impacts from ENSO events and dams. Glob. Planet. Chang. 2006, 50, 212-225. [CrossRef]

48. Zhang, X.B.; Yang, F. RClimDex (1.0) User Manual. Available online: http://etccdi.Pacificclimate.org/software. shtml (accessed on 10 September 2004).

49. Choi, G.; Collins, D.; Ren, G.Y.; Trewin, B.; Baldi, M.; Fukuda, Y.; Afzaal, M.; Pianmana, T.; Gomboluudev, P.; Huong, P.T.T.; et al. Changes in means and extreme events of temperature and precipitation in the Asia-Pacific Network region, 1955-2007. Int. J. Climatol. 2009, 29, 1906-1925. [CrossRef]

50. Vincent, L.A.; Aguilar, E.; Saindou, M.; Hassane, A.F.; Jumaux, G.; Roy, D.; Booneeady, P.; Virasami, R.; Randriamarolaza, L.Y.A.; Faniriantsoa, F.R.; et al. Observed trends in indices of daily and extreme temperature and precipitation for the countries of the western Indian Ocean, 1961-2008. J. Geophys. Res. Atmos. 2011, 116, 521-541. [CrossRef]

51. Yu, L.J.; Sui, C.J.; Lenschow, D.H.; Zhou, M.Y. The relationship between wintertime extreme temperature events north of $60^{\circ} \mathrm{N}$ and large scale atmospheric circulations. Int. J. Climatol. 2017, 37, 597-611. [CrossRef]

52. Zhang, Q.; Xu, C.Y.; Gemmer, M.; Chen, Y.D.; Liu, C.L. Changing properties of precipitation concentration in the Pearl river basin, China. Stoch. Env. Res. Risk A 2009, 23, 377-385. [CrossRef] 
53. Zhang, K.X.; Pan, S.M.; Cao, L.G.; Wang, Y.; Zhao, Y.F.; Zhang, W. Spatial distribution and temporal trends in precipitation extremes over the Hengduan Mountains region, China, from 1961 to 2012. Quatern. Int. 2014, 349, 346-356. [CrossRef]

54. Guan, Y.H.; Zheng, F.L.; Zhang, X.C.; Wang, B. Trends and variability of daily precipitation and extremes during 1960-2012 in the Yangtze River basin, China. Int. J. Climatol. 2016, 37, 1282-1298. [CrossRef]

55. Alexander, L.V.; Zhang, X.; Peterson, T.C.; Caesar, J.; Gleason, B.; Klein, A.; Haylock, M.; Collins, D.; Trewin, B.; Rahimzadeh, F.; et al. Global observed changes in daily climate extremes of temperature and precipitation. J. Geophys. Res. Atmos. 2006, 111, 1042-1063. [CrossRef]

56. Li, Z.X.; He, Y.Q.; Wang, P.Y.; Theakstone, W.H.; An, W.L.; Wang, X.F. Changes of daily climate extremes in southwestern China during 1961-2008. Glob. Planet. Chang. 2012, 80-81, 255-272. [CrossRef]

57. Pei, F.S.; Wu, C.J.; Liu, X.P.; Hu, Z.L.; Xia, Y.; Liu, L.A.; Wang, K.; Zhou, Y. Detection and attribution of extreme precipitation changes from 1961 to 2012 in the Yangtze River Delta in China. Catena 2018, 169, 183-194. [CrossRef]

58. Gao, T.; Xie, L.; Liu, B. Association of extreme precipitation over the Yangtze River basin with global air-sea heat fluxes and moisture transport. Int. J. Climatol. 2015, 36, 3020-3038. [CrossRef]

59. Tian, Q.; Prange, M.; Merkel, U. Precipitation and temperature changes in the major chinese river basins during 1957-2013 and links to sea surface temperature. J. Hydrol. 2016, 536, 208-221. [CrossRef]

60. Yu, L.; Rienecker, M.M. Evidence of an extra-tropical atmospheric influence during the onset of the 1997-98 El Nino. Geophys. Res. Lett. 1998, 25, 3537-3540. [CrossRef]

61. Zhong, K.Y.; Zheng, F.L.; Wu, H.Y.; Qin, C.; Xu, X.M. Dynamic changes in temperature extremes and their association with atmospheric circulation patterns in the Songhua River Basin, China. Atmos. Res. 2017, 190, 77-88. [CrossRef]

62. Shi, J.; Cui, L.L.; Ma, Y.; Du, H.Q.; Wen, K.M. Trends in temperature extremes and their association with circulation patterns in China during 1961-2015. Atmos. Res. 2018, 212, 259-272. [CrossRef]

63. Wang, W.G.; Shao, Q.X.; Yang, T.; Peng, Z.Z.; Yu, Z.B.; Taylor, J.; Xing, W.Q.; Zhao, C.P.; Sun, F.C. Changes in daily temperature and precipitation extremes in the Yellow River Basin, China. Stoch. Env. Res. Risk A 2013, 27, 401-421. [CrossRef] 